\title{
Analysis of cotton water productivity in Fergana Valley of Central Asia
}

\author{
J. Mohan Reddy ${ }^{1 *}$, Shukhrat Muhammedjanov ${ }^{2}$, Kahramon Jumaboev ${ }^{1}$, Davron Eshmuratov ${ }^{1}$ \\ ${ }^{1}$ International Water Management Institute, Tashkent, Uzbekistan; ${ }^{*}$ Corresponding Author: m.junna@,cgiar.org \\ ${ }^{2}$ Scientific Information Center of the Interstate Committee for Water Coordination, Tashkent, Uzbekistan
}

Received 15 June 2012; revised 21 July 2012; accepted 6 August 2012

\section{ABSTRACT}

Cotton water productivity was studied in Fergana Valley of Central Asia during the years of 2009, 2010 and 2011. Data was collected from 18 demonstration fields (13 in Uzbekistan, 5 in Tajikistan). The demonstration field farmers implemented several improved agronomic and irrigation water management practices. The average values of crop yield, estimated crop consumptive use $\left(E T_{a}\right)$ and total water applied (TWA) for the demonstration sites were, respectively, 3700 $\mathrm{kg} / \mathrm{ha}, 6360 \mathrm{~m}^{3} / \mathrm{ha}$, and $8120 \mathrm{~m}^{3} / \mathrm{ha}$. The range of values for TWA and $\mathrm{ET}_{\mathrm{a}}$ were, respectively, 5000 $\mathrm{m}^{3} / \mathrm{ha}$ to $12,000 \mathrm{~m}^{3} / \mathrm{ha}$ and $4500 \mathrm{~m}^{3} / \mathrm{ha}$ to 8000 $\mathrm{m}^{3} / \mathrm{ha}$. A quadratic relationship was found between TWA and $\mathrm{ET}_{\mathrm{a}}$. The average yield of the adjacent fields was $3300 \mathrm{~kg} / \mathrm{ha}$, whereas the average yield of cotton in Fergana Valley as a whole was $2900 \mathrm{~kg} / \mathrm{ha}$, indicating $28 \%$ and $14 \%$ increase in crop yield, respectively, from, demonstration fields and adjacent fields. There was no significant difference in crop yields between the wet years (2009 and 2010) and the dry year (2011), which is explained by the quadratic relationship between TWA and $\mathrm{ET}_{\mathrm{a}}$. The water productivity values ranged from $0.35 \mathrm{~kg} / \mathrm{m}^{3}$ to 0.89 $\mathrm{kg} / \mathrm{m}^{3}$, indicating a significant potential for improving water productivity through agronomic and irrigation management interventions. The ratio of average $\mathrm{ET}_{\mathrm{a}}$ divided by average TWA gave an average application efficiency of $78 \%$ (some fields under-irrigated and some fields over-irrigated), the remaining $22 \%$ of water applied leaving the field. Since more than $60 \%$ of the water used for irrigation in Tajikistan and Uzbekistan is pumped from, even if all this $22 \%$ of water returns to the stream, substantial energy savings would accrue from improving the average application efficiency at field level. The range of values for TWA indicates the inequity in water distribution/accessibility. Addressing this inequity would also increase water productivity at field and project level.

Keywords: Furrow Irrigation of Cotton; Irrigation in Fergana Valley; Water Productivity

\section{INTRODUCTION}

After independence from the former Soviet Union (in 1991), the operation and maintenance of irrigation and drainage systems was neglected due to lack of adequate financial resources. This exacerbated the pre-existing problem of waterlogging and salinity of irrigated lands. In Central Asia as a whole, more than 5.97 million ha of irrigated area out of the total irrigated area of 8 million hectares requires artificial drainage. There were significant investments in drainage in the region until 1990s. However, with the collapse of the Soviet Union, drainage systems are no longer properly maintained and the area under waterlogging and salinity has been steadily increasing: $35 \%$ increase in waterlogged area and $62 \%$ increase in area under moderate to high salinity [1].

Furthermore, the State/Collective farms disintegrated, with nobody to claim the ownership of irrigation and drainage infrastructure. Land was distributed to local people, irrespective of their prior background in agriculture. In Kyrgyzstan, Kazakhstan and Tajikistan, farmers own their land, whereas in Turkmenistan and Uzbekistan farmers lease their land from the government. Disintegration of large farms has increased the number of farmers the majority of whom have inadequate knowledge/ skills of irrigated agriculture. There was insufficient onfarm irrigation infrastructure to distribute water to individual farmers. During the Soviet era, every State/Collective farm had professional agronomists and irrigation specialists for providing advisory services for irrigated agriculture. However, with the collapse of the system, some of this expertise was lost. Without adequate irrigation infrastructure and organizational support for water distribution below the tertiary canal level, irrigated agri- 
culture became chaotic-head-end/tail-end problems, inequity and unreliability in water supply, lack of advisory services on agricultural practices, lack of appropriate farm machinery for operation on small farms, etc.

After year 2000, through Agricultural Reform Acts, Water Users Associations (WUAs) have been formed. This process is not complete in Tajikistan and Turkmenistan. The Government agencies provide bulk water supply to WUAs, and then it is the responsibility of WUAs to supply this water equitably to individual farmers. Yet, there are problems of equity and unreliability of water supply within WUAs hindering improved water management at plot level. This situation combined with waterlogging and salinity has resulted in significant reducetions in crop yields.

With a view to increase crop yields from irrigated agriculture, the Swiss Agency for Development and Cooperation (SDC) financed a project for improving water productivity at plot level (WPI-PL). The project had two objectives. The first objective of the project was to develop and evaluate an effective mechanism called "Innovation Cycle" for dissemination of knowledge on improving water productivity to farmers in the Fergana Valley of Central Asia on an experimental basis. This objective was accomplished successfully during the three year period of the project. A separate paper is being prepared on the structure and functioning of the developed Innovation Cycle. The second objective of the project was to evaluate the effect of the Innovation Cycle on improving water productivity of agricultural crops in Fergana Valley. To this end, data on irrigated agricultural production of several major crops such as cotton and wheat, and other crops such as potato, maize, sunflower, watermelons, cucumbers, onions, etc., were collected from several demonstration sites in the countries of Kyrgyzstan, Tajikistan and Uzbekistan. In the past, some general studies were undertaken on water productivity of major crops (cotton and rice) in Syr Darya basin $[2,3]$.

However, no water productivity studies were conducted at field level after implementing the Agricultural Reform Acts of early 2000's. In addition, no data are available on water productivity of agricultural crops under improved agronomic and irrigation water management practices because no effective mechanisms for dissemination of irrigated agriculture knowledge exist in Central Asia today. This paper discusses cotton water productivity from demonstration fields in Tajikistan and Uzbekistan that received irrigated agriculture advisory services from the WPI-PL project.

\section{DESCRIPTION OF SITE}

To assess cotton water productivity at field level, dem- onstration sites were selected in Fergana Valley of Central Asia. Fergana Valley is located in the Southeastern part of Central Asia region and the Eastern part of Aral Sea basin, and its territory is shared by three countriesKyrgyzstan, Tajikistan and Uzbekistan. The Fergana Valley forms the upper and mid-reach of the Syr Darya Basin. Syr Darya is formed from the confluence of Naryn and Karadarya rivers. The average temperature in the Valley is $13.1^{\circ} \mathrm{C}$, ranging from $-8^{\circ} \mathrm{C}$ to $3^{\circ} \mathrm{C}$ in January and from $17^{\circ} \mathrm{C}$ to $36^{\circ} \mathrm{C}$ in July. Annual precipitation varies from $109 \mathrm{~mm}$ to $502 \mathrm{~mm}$, whereas evaporation ranges from $1133 \mathrm{~mm}$ to $1294 \mathrm{~mm}$ throughout Fergana Valley. Fergana Valley is home for $11,342,000$ people over an area of $124,200 \mathrm{~km}^{2}$.

Data on water productivity were collected from a total of 23 demonstration sites - 13 sites in Uzbekistan, 5 sites in Kyrgyzstan, and 5 sites in Tajikistan. The main criterion used in the selection of demonstration sites was that the farmer must be a "progressive farmer", i.e. a farmer with background in irrigated agriculture and was willing to experiment with innovative agronomic and irrigation practices. All the selected demonstration site farmers in Kyrgyzstan did not grow cotton. Therefore, data only from the remaining 18 sites was used to calculate water productivity of cotton. The location of these 18 sites is presented in Figure 1. At each of these 18 demonstration farms, an adjacent farm was also selected for comparison purposes.

For all the 18 demonstration fields, information on soil texture, soil-moisture content at field capacity, and depth of watertable from ground surface was collected (Table 1). Soil salinity is not an issue at most of the demonstration sites. All the fields practiced furrow irrigation, with runoff from the downstream-end of the fields. The fields are sloping with undulations. No data was collected on the degree of undulations in each field. Flow measurement structures were installed at all the demonstration sites to measure the amount of irrigation water applied to the fields and the amount of runoff from the fields. Information on the irrigation norms (based upon hydromodule zoning) was also provided to relevant WUAs. In Uzbekistan, cotton crop is mandated to be grown in order to meet the annual production quota that is determined by the government. In order to facilitate the meeting of total national quota, a target yield level is set for each field based upon the soil-texture, soil fertility, condition of watertable, level of soil salinity and salinity of water used for irrigation. In addition, farmers are provided with credit facilities for acquiring the necessary agricultural inputs. Farmers are required to produce cotton yields that are at least equal to the target level set by the government. If any farmer fails to meet the production target, his/her land lease will be re-negotiated. Furthermore, the farmers are expected to sell cotton only to the government. Cot- 


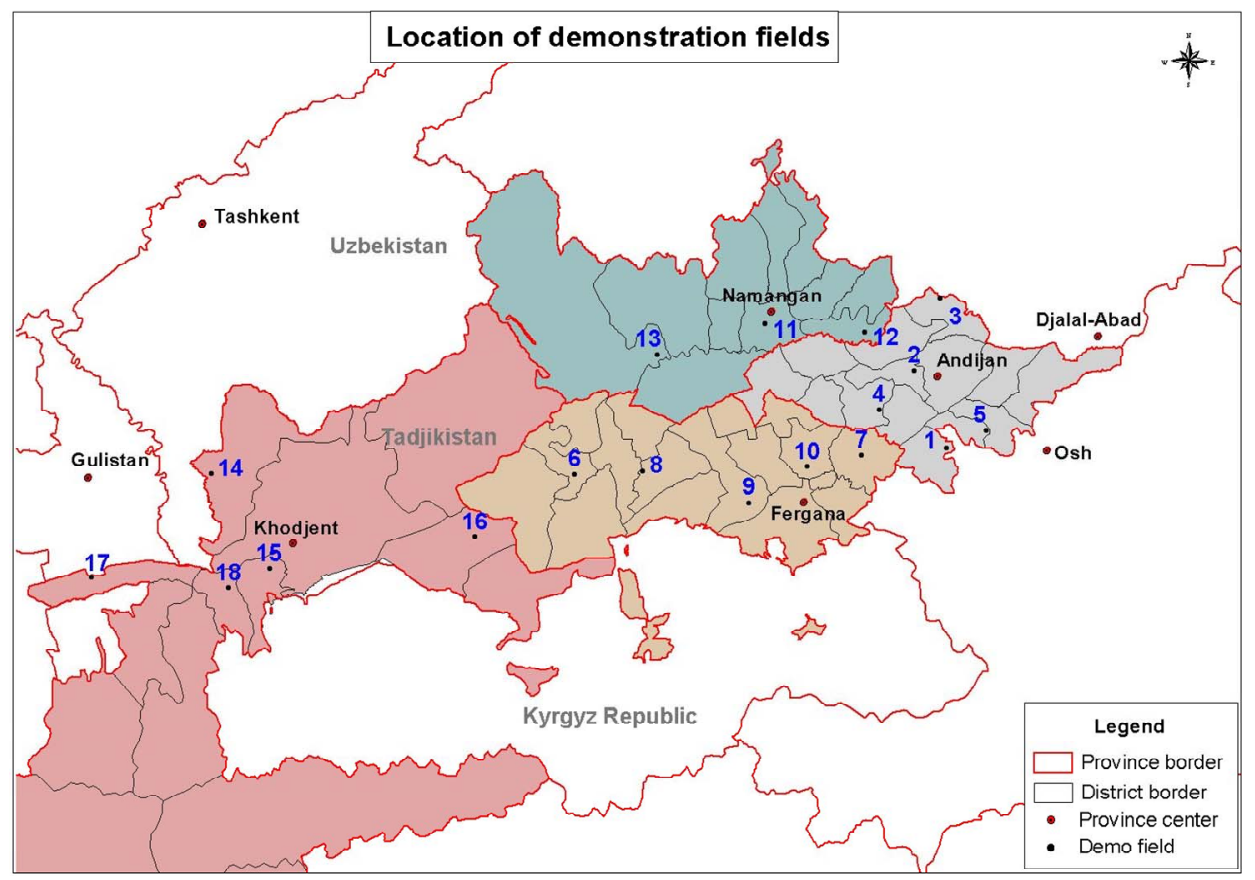

Figure 1. Location of demonstration sites in Tajikistan and Uzbekistan.

Table 1. Field capacity and depth to watertable of demonstration sites in Tajikistan and Uzbekistan.

\begin{tabular}{|c|c|c|c|}
\hline Province & Site № & $\begin{array}{l}\text { Field capacity, } \\
\mathrm{mm} / \mathrm{m}\end{array}$ & $\begin{array}{c}\text { Depth to } \\
\text { Watertable, } \mathrm{cm}\end{array}$ \\
\hline \multirow{5}{*}{ Andijon } & 1 & 177 & $>300$ \\
\hline & 2 & 181 & 150 \\
\hline & 3 & 184 & $>300$ \\
\hline & 4 & 167 & 200 \\
\hline & 5 & 189 & $>300$ \\
\hline \multirow{5}{*}{ Fergana } & 6 & 192 & 160 \\
\hline & 7 & 173 & 160 \\
\hline & 8 & 166 & 150 \\
\hline & 9 & 139 & 140 \\
\hline & 10 & 125 & 250 \\
\hline \multirow{3}{*}{ Namangan } & 11 & 150 & $>300$ \\
\hline & 12 & 184 & 150 \\
\hline & 13 & 192 & $>300$ \\
\hline \multirow{5}{*}{ Sogd } & 14 & 167 & $>300$ \\
\hline & 15 & 192 & $>300$ \\
\hline & 16 & 167 & $>300$ \\
\hline & 17 & 125 & $>300$ \\
\hline & 18 & 192 & $>300$ \\
\hline
\end{tabular}

ton is not a mandated crop in Tajikistan; therefore, no government financed credit facilities are provided to farmers. Though the farmers in Tajikistan have the incentive to produce high yields of cotton, lack of credit may be a constraint for increasing agricultural production per unit area. In addition, farmers' income is also vulnerable to the world market prices.

All the demonstration site farmers received information on a set of innovative agronomic and irrigation practices to improve water productivity at field level (Table 2). These innovative practices included: land preparation, agro-ameliorative certification of farms, proper sizing of irrigation schemes, mixing of mineral fertilizers with organic fertilizers (manure), application of liquid mineral fertilizers through irrigation water in furrows, adoption of volumetric water delivery method, irrigation scheduleing, measurement of irrigation flow using Sokolok method, short furrow irrigation, alternate furrow irrigation, installation of plastic films at the head of furrows, runoff recovery, cutback irrigation, water rotation, interrow cultivation, and leaching of salts. As shown in Table 2, most of these recommendations were implemented by several demonstration field farmers. Almost all the farmers used alternate furrow irrigation, short furrow irrigation, good pest control measures, inter-row cultivation, and re-use of runoff water from fields.

In order to calculate the net benefits accrued to the demonstration farm farmers, the following information was collected: type and kilogram of seed farmer applied per hectare, amount and cost of fertilizer and pesticides used per hectare, cost of equipment for tillage and culti- 
Table 2. Technologies used at demonstration sites.

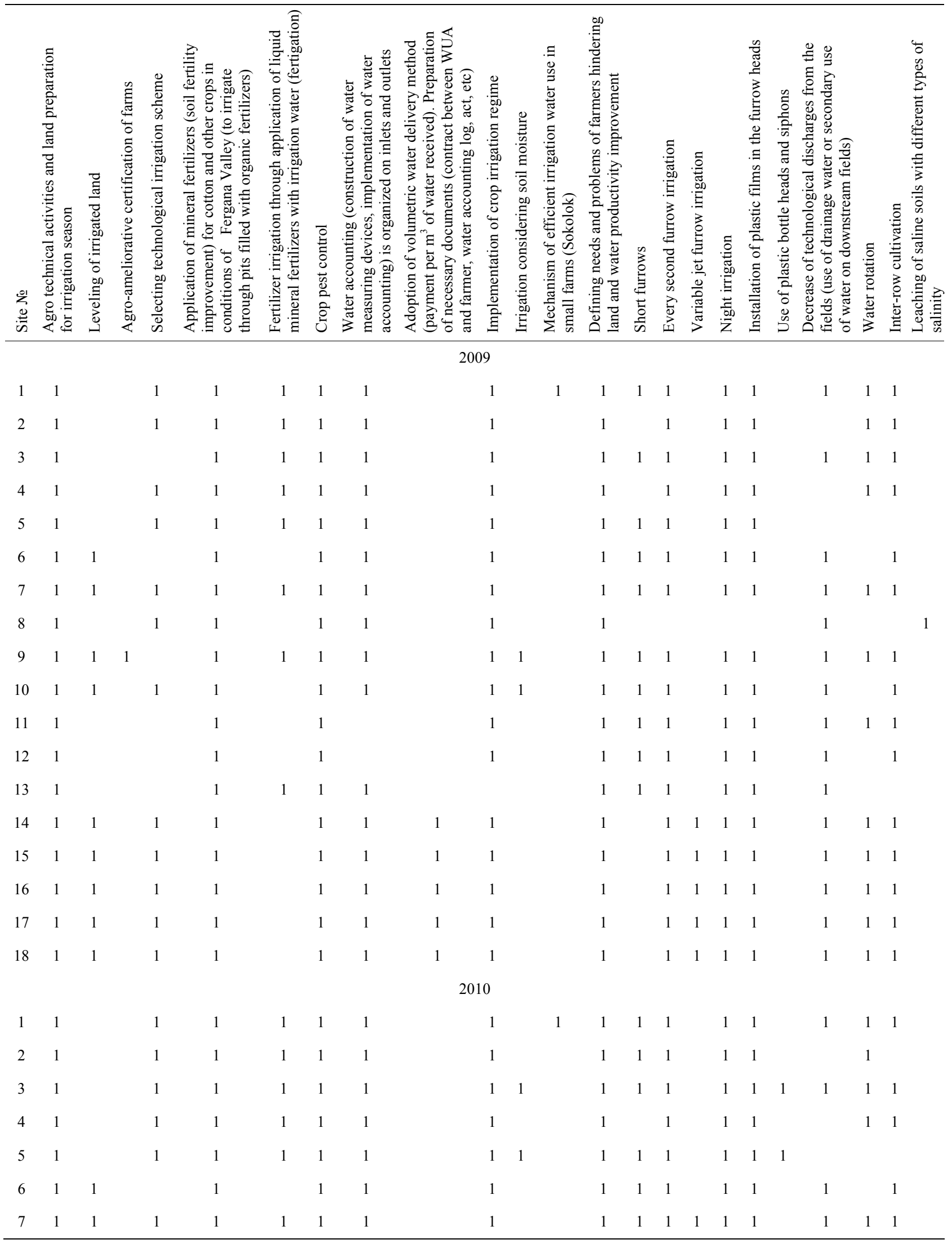




\begin{tabular}{|c|c|c|c|c|c|c|c|c|c|c|c|c|c|c|c|c|c|c|c|c|c|c|c|}
\hline \multicolumn{24}{|c|}{ Continued } \\
\hline 8 & 1 & 1 & & 1 & 1 & 1 & 1 & 1 & & 1 & & & 1 & 1 & & & 1 & 1 & & 1 & & & 1 \\
\hline 9 & 1 & 1 & 1 & & 1 & 1 & 1 & 1 & & 1 & 1 & & 1 & 1 & 1 & & 1 & 1 & & 1 & 1 & 1 & \\
\hline 10 & 1 & 1 & & 1 & 1 & & 1 & 1 & & 1 & 1 & & 1 & 1 & 1 & & 1 & 1 & & 1 & & 1 & \\
\hline 11 & 1 & 1 & 1 & & 1 & 1 & 1 & & & & & & 1 & & 1 & & 1 & 1 & & 1 & & 1 & \\
\hline 12 & 1 & 1 & 1 & & 1 & 1 & 1 & 1 & & & & & 1 & 1 & 1 & & 1 & 1 & & 1 & & & \\
\hline 14 & 1 & 1 & & 1 & 1 & & 1 & 1 & 1 & 1 & & & 1 & & 1 & 1 & 1 & 1 & & 1 & 1 & 1 & \\
\hline 15 & 1 & 1 & & 1 & 1 & & 1 & 1 & 1 & 1 & & 1 & 1 & 1 & 1 & 1 & 1 & 1 & & 1 & 1 & 1 & \\
\hline 16 & 1 & 1 & & 1 & 1 & & 1 & 1 & 1 & 1 & & 1 & 1 & 1 & 1 & 1 & 1 & 1 & & 1 & 1 & 1 & \\
\hline 17 & 1 & 1 & & 1 & 1 & & 1 & 1 & 1 & 1 & & 1 & 1 & 1 & 1 & 1 & 1 & 1 & & 1 & 1 & 1 & \\
\hline 18 & 1 & 1 & & 1 & 1 & & 1 & 1 & 1 & 1 & & 1 & 1 & 1 & 1 & 1 & 1 & 1 & & 1 & 1 & 1 & \\
\hline \multicolumn{24}{|c|}{2011} \\
\hline 1 & 1 & & & 1 & 1 & 1 & 1 & 1 & & 1 & & 1 & 1 & 1 & 1 & & 1 & 1 & & 1 & 1 & 1 & \\
\hline 2 & 1 & & & 1 & 1 & 1 & 1 & 1 & & 1 & 1 & & 1 & 1 & 1 & & 1 & 1 & & & 1 & & \\
\hline 3 & 1 & & & 1 & 1 & 1 & 1 & 1 & & 1 & 1 & & 1 & 1 & 1 & & 1 & 1 & 1 & 1 & 1 & 1 & \\
\hline 5 & 1 & & & 1 & 1 & 1 & 1 & 1 & & 1 & 1 & & 1 & 1 & 1 & & 1 & 1 & 1 & & 1 & 1 & \\
\hline 7 & 1 & 1 & & 1 & 1 & 1 & 1 & 1 & & 1 & & & 1 & 1 & 1 & 1 & 1 & 1 & & 1 & 1 & 1 & \\
\hline 8 & 1 & 1 & & 1 & 1 & 1 & 1 & 1 & & 1 & & & 1 & 1 & & & 1 & 1 & & 1 & & & 1 \\
\hline 9 & 1 & 1 & 1 & & 1 & 1 & 1 & 1 & & 1 & 1 & & 1 & 1 & 1 & & 1 & 1 & & 1 & & 1 & \\
\hline 10 & 1 & 1 & & 1 & 1 & & 1 & 1 & & 1 & 1 & & 1 & 1 & 1 & & 1 & 1 & & 1 & & 1 & \\
\hline 11 & 1 & 1 & 1 & & 1 & 1 & 1 & & & 1 & & & 1 & & 1 & & 1 & 1 & & 1 & & 1 & \\
\hline 14 & 1 & 1 & & 1 & 1 & & 1 & 1 & 1 & 1 & 1 & 1 & 1 & 1 & 1 & 1 & 1 & 1 & & 1 & 1 & 1 & \\
\hline 15 & 1 & 1 & & 1 & 1 & & 1 & 1 & 1 & 1 & 1 & 1 & 1 & 1 & 1 & 1 & 1 & 1 & & 1 & 1 & 1 & \\
\hline 17 & 1 & 1 & & 1 & 1 & & 1 & 1 & 1 & 1 & 1 & 1 & 1 & 1 & 1 & 1 & 1 & 1 & & 1 & 1 & 1 & \\
\hline 18 & 1 & 1 & & 1 & 1 & & 1 & 1 & 1 & 1 & & 1 & 1 & 1 & 1 & 1 & 1 & 1 & & 1 & 1 & 1 & \\
\hline
\end{tabular}

vation, cost of labor, amount of irrigation water applied per hectare, cost of transportation, fixed costs for agricultural production, and finally yield of major crops. In addition, climatic data from the nearest weather station for each of the 18 sites was gathered for calculating reference evapotranspiration of cotton crop at the given locations.

\section{METHODOLOGY TO CALCULATE WATER PRODUCTIVITY}

There are several definitions of water productivity (WP). The most commonly used definition [4] is given as the ratio of the crop yield, $\mathrm{Y}_{\text {crop }}(\mathrm{kg} / \mathrm{ha})$, divided by the consumptive use of water by the crop, $\mathrm{ET}_{\mathrm{a}}\left(\mathrm{m}^{3} / \mathrm{ha}\right)$, i.e.

$$
\mathrm{WP}=\mathrm{Y}_{\text {crop }} / \mathrm{ET}_{\mathrm{a}}
$$

in which $Y_{\text {crop }}=$ measured crop yield under natural and irrigated conditions, $\mathrm{kg} / \mathrm{ha}$; and $\mathrm{ET}_{\mathrm{a}}=$ estimated/measured seasonal evapotranspiration or crop water use, $\mathrm{m}^{3} / \mathrm{ha}$. The above definition is independent of the source of water made available for $\mathrm{ET}_{\mathrm{a}}$, and assumes that any water losses that occur at field level, in the form of runoff and deep percolation, are recaptured and re-used somewhere else in the basin, ignoring or discounting some "co-benefits" such as improved water quality (particularly under Central Asian conditions where salinity is a major issue), increased crop production, increased reliability in water supply, decreased energy demands and carbon emissions, and reduced or delayed infrastructure investments [5] that accrue from improved application efficiency at field level. The source of water for $\mathrm{ET}_{\mathrm{a}}$ may be a combination of one or more of the following: rainfall, groundwater, residual soil-moisture from previous season or irrigation water.

Sometimes, we are interested in the incremental change 
in crop yields due to the addition of irrigation water to fields. Therefore, another productivity term called irrigation water productivity [6] is defined as follows:

$$
\mathrm{WP}_{\mathrm{I}}=\left(\mathrm{Y}_{\text {crop }}-\mathrm{Y}_{\mathrm{D}}\right) / \mathrm{V}_{\mathrm{I}}
$$

in which $\mathrm{WP}_{\mathrm{I}}=$ irrigation water productivity of crop, $\mathrm{kg} / \mathrm{m}^{3} ; \mathrm{Y}_{\mathrm{D}}=$ crop yield under dryland conditions (rainfall, residual initial soil-moisture content from previous season, groundwater contribution) without any irrigation, $\mathrm{kg} / \mathrm{ha} ; \mathrm{V}_{\mathrm{I}}=$ cumulative volume of irrigation water applied during the crop growing season, $\mathrm{m}^{3} /$ ha. To calculate $\mathrm{WP}_{\mathrm{I}}$, information on crop production $\mathrm{Y}_{\mathrm{D}}$ at different levels of natural water supply must be available.

The water productivity definitions provided above (Eqs.1 and 2) do not provide any indication of inefficiency of water application at field level. Sometimes, farmers apply $50 \%$ to $100 \%$ more water than the amount of water required by the crop; yet, the actual water use by crop $\left(\mathrm{ET}_{\mathrm{a}}\right)$ only goes up slightly compared to its water use under normal conditions. In order to capture the inefficiency of water use by farmers, the following definition of water productivity is proposed here:

$$
\mathrm{WP}_{\mathrm{G}}=\mathrm{Y}_{\text {crop }} / \mathrm{V}_{\text {all }}
$$

in which $\mathrm{WP}_{\mathrm{G}}=$ gross water productivity, $\mathrm{kg} / \mathrm{m}^{3}$; and $\mathrm{V}_{\text {all }}$ $=$ volume of water applied to a field from all sources (rainfall, residual soil-moisture, groundwater, and irrigation water), $\mathrm{m}^{3} / \mathrm{ha}$, and is calculated as follows:

$$
\mathrm{V}_{\mathrm{all}}=\mathrm{V}_{\text {irri }}+\mathrm{V}_{\mathrm{GW}}+\mathrm{V}_{\text {imc }}+\mathrm{V}_{\text {rainfall }}
$$

in which $\mathrm{V}_{\text {irri }}=$ volume of irrigation water applied to a field, $\mathrm{m}^{3} / \mathrm{ha} ; \mathrm{V}_{\mathrm{GW}}=$ volume of groundwater contribution to crop root zone, $\mathrm{m}^{3} / \mathrm{ha} ; \mathrm{V}_{\mathrm{imc}}=$ volume of initial soilmoisture content at the time of planting, $\mathrm{m}^{3} / \mathrm{ha}$; and $\mathrm{V}_{\text {rainfall }}$ $=$ volume of rainfall received on the field during the crop growing season, $\mathrm{m}^{3} /$ ha.

In order to calculate WP using Eq.1, the seasonal crop water use $\left(\mathrm{ET}_{\mathrm{a}}\right)$ must be estimated for the given location. The most accurate methods of measuring $\mathrm{ET}_{\mathrm{a}}$ are lysimeters, neutron probes, and gravimetric methods. However, since the 18 demonstration sites were scattered over a large area, and since no lysimeters and neutron probes were available, the $\mathrm{ET}_{\mathrm{a}}$ was estimated using a standard soil-moisture balance equation $[6,7]$ :

$$
\mathrm{ET}_{\mathrm{a}}=\mathrm{R}+\mathrm{I}+\mathrm{F}-\mathrm{Rf}-\Delta \mathrm{S}
$$

in which $\mathrm{ET}_{\mathrm{a}}=$ seasonal crop evapotranspiration or water use, $\mathrm{mm} ; \mathrm{R}=$ rainfall during the growing season, $\mathrm{mm}$; I = irrigation amount applied during the growing season, $\mathrm{mm} ; \mathrm{F}=$ net soil-moisture flux (taken positive into the rootzone) at the bottom of the crop rootzone, $\mathrm{mm}$; $\mathrm{Rf}=$ runoff from the soil-surface, $\mathrm{mm}$; and $\Delta \mathrm{S}=$ change in soil-moisture content (taken as positive when the soilmoisture content increases over the season) within the crop rootzone during the crop growth season, mm. All the quantities on the right-hand-side of Eq.5 must be carefully estimated in order to estimate seasonal crop water use. In using Eq.5, the most difficult variable to estimate is $\mathrm{F}$, the net soil-moisture flux from/to the crop rootzone. In the absence of a high watertable, the net soil-moisture flux is always negative, and is basically due to deep percolation from irrigation and/or rainfall amount added to the crop rootzone. The change in the rootzone soil-moisture content is typically estimated using gravimetric sampling or neutron moisture meter. If a lysimeter is used, all the quantities on the right-hand-side of Eq.6 are measured in order to compute the crop consumptive use on a daily, weekly, or seasonal basis. In the absence of lysimeters and soil-moisture sensing devices, a different method can be used to estimate the seasonal consumptive water use $\left(\mathrm{ET}_{\mathrm{a}}\right)$ of a given crop. It is given as follows:

$$
\mathrm{ET}_{\mathrm{a}}=\Sigma \mathrm{ET}_{\mathrm{a}}(\mathrm{i}), \quad \mathrm{i}=1 \text { to } \mathrm{N}
$$

in which $\mathrm{ET}_{\mathrm{a}}(\mathrm{i})$ = estimated crop evapotranspiration on day $\mathrm{i}, \mathrm{mm} /$ day; and $\mathrm{N}=$ number of days in the growth period for the given crop. $\mathrm{ET}_{\mathrm{a}}(\mathrm{i})$ is estimated as follows:

$$
\operatorname{ET}_{\mathrm{a}}(\mathrm{i})=\mathrm{K}_{\mathrm{c}}(\mathrm{i}) \mathrm{K}_{\mathrm{s}}(\mathrm{i}) \mathrm{ET}_{\mathrm{r}}(\mathrm{i})
$$

in which $\mathrm{ET}_{\mathrm{r}}(\mathrm{i})$ = estimated evapotranspiration of a reference crop on day $i$, typically estimated using the available climatic data, $\mathrm{mm} / \mathrm{day} ; \mathrm{K}_{\mathrm{c}}(\mathrm{i})=$ crop coefficient values as a function of different growth periods of the given crop; and $\mathrm{K}_{\mathrm{s}}(\mathrm{i})=$ soil-moisture stress coefficient on day $\mathrm{i}$ which is related to the maximum available soil-moisture content and the actual soil-moisture content in the rootzone on day i. In the literature, three different types of relationships are provided between $\mathrm{K}_{\mathrm{s}}$ and the soilmoisture content in the rootzone. The following relationship is used in this paper:

$$
\mathrm{K}_{\mathrm{s}}(\mathrm{i})=\ln (1+\mathrm{PAW}(\mathrm{i})) / \ln (101)
$$

in which PAW(i) = percent available water within the crop rootzone on day $\mathrm{i}$, and is calculated using

$$
\operatorname{PAW}(\mathrm{i})=100\left(\theta_{\mathrm{a}}-\theta_{\mathrm{wp}}\right) /\left(\theta_{\mathrm{fc}}-\theta_{\mathrm{wp}}\right)
$$

in which $\theta_{\mathrm{fc}}=$ soil-moisture content at field capacity, mm; $\theta_{\mathrm{wp}}=$ soil-moisture content at wilting point, mm; and $\theta_{\mathrm{a}}$ $=$ actual soil-moisture content, $\mathrm{mm}$. Soil-moisture content on a volume-basis is calculated using the following equation:

$$
\theta=\varphi \gamma_{\mathrm{bd}} \mathrm{z}_{\mathrm{r}}(\mathrm{t})
$$

in which $\theta=$ soil-moisture content on a volume-basis; $\varphi=$ soil-moisture content on a weight-basis; $\gamma_{\mathrm{bd}}=$ soil bulk density; and $\mathrm{z}_{\mathrm{r}}(\mathrm{t})=$ crop rooting depth, $\mathrm{mm}$. Since it is tedious to measure soil-moisture content, $\theta_{\mathrm{a}}$, on a daily basis, frequently a soil-moisture balance equation is used 
to estimate $\theta_{\mathrm{a}}$ on a daily basis

$$
\theta_{\mathrm{a}}(\mathrm{i}+1)=\theta_{\mathrm{a}}(\mathrm{i})+\mathrm{I}(\mathrm{i})+\mathrm{R}(\mathrm{i})-\mathrm{ET}_{\mathrm{a}}(\mathrm{i})+\mathrm{GW}(\mathrm{i})
$$

in which $\mathrm{i}=$ index of day; $\mathrm{I}(\mathrm{i})=$ irrigation amount on day $\mathrm{i}, \mathrm{mm} ; \mathrm{R}(\mathrm{i})=$ rainfall amount on day $\mathrm{i}, \mathrm{mm}$; and $\mathrm{GW}(\mathrm{i})=$ groundwater contribution on day i, mm. To use Eq.11, information on the soil-moisture content on the day of planting $(i=1)$, the dates and amounts of irrigation water applied (minus runoff from field), the dates and amounts of rainfall, and groundwater contribution to the crop rootzone on a daily basis must be known. Groundwater contribution, in $\mathrm{mm} / \mathrm{day}$, to the crop rootzone depends upon the soil texture, the evaporative demand of the atmosphere, and the depth of the watertable from the ground surface. Figure 2 shows the dependence of groundwater contribution to crop rootzone as a function of soil-texture and depth of watertable from the ground surface [8]. Information from this graph was used to estimate groundwater contribution to crop rootzone on a daily basis.

In Eq.7, the $\mathrm{ET}_{\mathrm{r}}$ was estimated using the PenmanMonteith equation [9] along with the local climatic data available from the weather stations operated by the Meteorological Departments of Uzbekistan and Tajikistan. The daily climatic data on sunshine hours, solar radiation, minimum and maximum temperatures and wind speed were available from the weather stations. The reference crop considered was short grass. Since there were no locally calibrated crop coefficients for cotton, the crop coefficients for cotton were obtained from FAO-56 report [9]. Since crop coefficients depend upon the climatic conditions and growth characteristics of given crop vari- ety, use of general crop coefficients provided in FAO-56 might introduce some error in the estimation of $\mathrm{ET}_{\mathrm{a}}$, and this error was considered acceptable for the current largescale study.

\section{RESULTS AND DISCUSSION}

Yield data for the 13 demonstration sites in Uzbekistan and the 5 demonstration sites in Tajikistan was obtained from the farmers. Crop yield data along with the cost of production, and net profits are presented in Table 3 for the years 2009, 2010 and 2011. During the 2010 and 2011 irrigation seasons, all the demonstration farmers did not grow cotton on their demonstration fields. Hence, the number of cotton fields was less than 18 . Yields of cotton from the demonstration sites ranged from $2000 \mathrm{~kg} /$ ha to $5500 \mathrm{~kg} /$ ha (Figure 3). This difference in yields was due to a combination of factors such as quality of advisory services received, the quality and quantity of seed used, the availability and quality of inputs received or applied by farmers, crop variety, and the irrigated cotton production knowledge-base of the farmers. Two things are obvious from Figure 3. First, the average yield of cotton from the demonstration sites in Tajikistan was lower (less than $3000 \mathrm{~kg} / \mathrm{ha}$ ) than the average yield of cotton from demonstration sites in Uzbekistan (about $3500 \mathrm{~kg} / \mathrm{ha}$ ). This difference in yields may be partly explained by the availability of credit for purchasing agricultural inputs plus application of land use practices which are also supported and monitored by the State. In Uzbekistan, since cotton is one of the two crops that is mandated by the State, the State provides the nec-

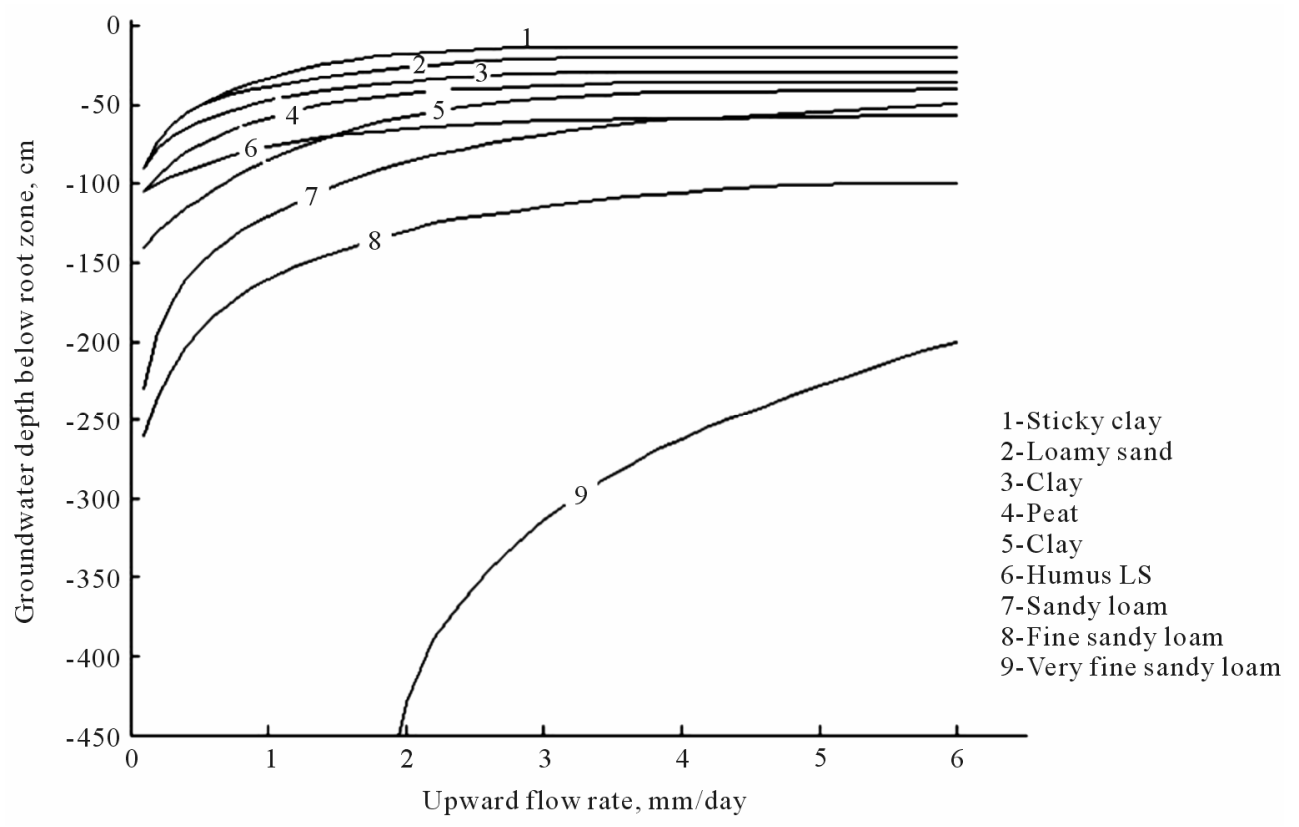

Figure 2. Groundwater contribution to crop rootzone. 


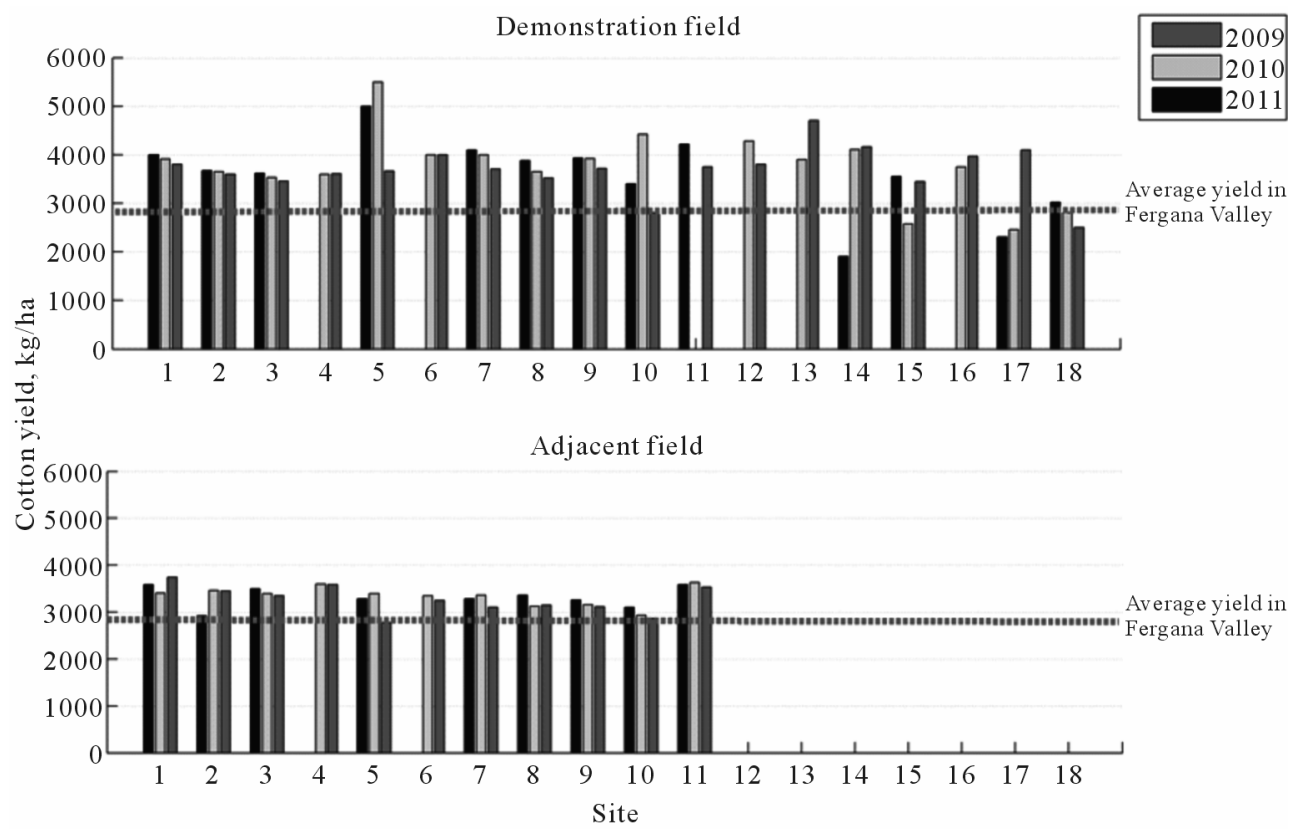

Figure 3. Cotton yields for the demonstration sites and the adjacent fields.

essary credit to farmers for purchasing all the necessary inputs to grow cotton, and the district-level government officials prod the farmers to apply irrigation water ontime according to the irrigation norms (though outdated), and to apply appropriate plant protection measures. Though data on the type and quantity of each input was collected, no information was collected on the quality and the timing of the inputs. In the case of Tajikistan, no such credit is available to farmers, and hence no such monitoring of inputs including water is done by the State. Secondly, as mentioned elsewhere, 2009 and 2010 (more rainfall and more water was available for irrigation during the vegetation period) were considered as wet years whereas 2011 was a dry year (less rainfall and less amount of irrigation water was available during the vegetation period). Yet, on the average, there was no significant difference in the yield of cotton between the wet and dry years. The farmers used irrigation water efficiently by under-irrigating the crop during the dry year. Under-irrigation was practiced not by choice, but by default!

Cotton yields from the adjacent fields are also shown in Figure 3. No data was available from the adjacent fields in Tajikistan. As expected, the average yields from the adjacent fields were lower (around $3300 \mathrm{~kg} / \mathrm{ha}$ ) than the average yields $(3700 \mathrm{~kg} / \mathrm{ha})$ obtained from the demonstration sites in Uzbekistan. The demonstration field farmers implemented a variety of "innovations" or improved agronomic and irrigation practices, as shown in Table 2, whereas the adjacent farmers were using one or more of the innovative practices implemented by the demonstration farmers. The average cotton yields in
Fergana Valley were about $2900 \mathrm{~kg} / \mathrm{ha}$, indicating that the average crop yields from the demonstration fields were $28 \%$ higher than the average crop yields in the area. From the above it is evident that there is a substantial opportunity to increase crop yields, and thus water productivity, in Fergana Valley through a combination of agronomic and irrigation water management intervenetions (Table 2). Since there was so much variability in the quality of inputs used at various demonstration sites (including crop varieties), it was not possible to identify the most important factors for increase in crop yields. Also, the yields of adjacent fields increased by $14 \%$ (above the average for Fergana Valley) suggesting that, with time, more farmers would adapt these interventions to raise the average yield of cotton in Fergana Valley. Some of the demonstration field farmers were using some additional innovative agronomic practices such as irradiation of seed, plastic mulching, and passing irrigation water through a magnetic field. All of these practices contributed to decent increases in crop yields. However, detailed field investigations are still underway to confirm and document the benefits of using these technologies so that they can be disseminated through the Innovation Cycle.

To estimate water productivity of cotton, the consumptive use of cotton crop was estimated using a simulation model (using Eqs.7-11 in an Excel Spreadsheet) on all the 18 sites. The total amount of water supplied from all the sources-initial soil-moisture content, groundwater contribution, irrigation, and rainfall was also calculated for all the 18 demonstration sites. Information on daily rainfall amounts (in millimeters) and daily weather 
conditions was obtained from the nearest weather station for each of the 18 demonstration sites. Then, the Penman-Monteith equation, as described in [9] was used to compute the daily evapotranspiration of a reference crop

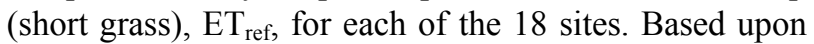
the depth of the watertable and the soil-texture, daily groundwater contributions to the crop rootzone were estimated using Figure 2. Information on dates and amounts of rainfall, daily groundwater contributions, daily $\mathrm{ET}_{\text {ref, }}$ and dates and amount of irrigation water infiltrated into the crop rootzone for each site was used to calculate soil-moisture balance (Eq.11) in the rootzone. In the simulation, the following assumptions were made:

1) The soil-moisture content in the crop rootzone was assumed to be close to field capacity at the beginning of the season.

2) The maximum rooting depth of cotton was assumed to be $1.6 \mathrm{~m}$. The active rooting depth at the beginning of the season was assumed to be $0.15 \mathrm{~m}$, and the rooting depth was assumed to increase to its maximum rooting depth linearly by the end of vegetative period.

3) In situations where there was a high watertable, the maximum rooting depth was set equal to the highest level of the watertable which typically occurred during the second half of the crop growth season.

4) If the calculated soil-moisture content on any given day was higher than the field capacity soil-moisture content for that soil, due to irrigation or rainfall, the soilmoisture content was set equal to the field capacity soilmoisture content for that soil.

These simulated values of daily soil-moisture content were used to calculate the daily soil-moisture stress coefficient, $\mathrm{K}_{\mathrm{s}}$, using Eq.8, which was then used to estimate the daily actual evapotranspiration, $\mathrm{ET}_{\mathrm{a}}$, of cotton. The daily $\mathrm{K}_{\mathrm{c}}$ values were obtained by linear interpolation of the values suggested by [9].

The seasonal amount of irrigation water applied, the rainfall amounts received, the groundwater contributions to crop rootzone, and the simulated total consumptive water use of cotton crop were calculated (Figure 4) for all the sites. It is clear from Figure 4 that the seasonal consumptive water use of cotton crop, $\mathrm{ET}_{\mathrm{a}}$, varied from $4500 \mathrm{~m}^{3} /$ ha to $8000 \mathrm{~m}^{3} / \mathrm{ha}$, depending upon the total amount of water supplied (TWA) from all sources, the timing of irrigations and rainfall amounts, and the local climatic conditions. The TWA to fields varied from 5000 $\mathrm{m}^{3} /$ ha to $12,000 \mathrm{~m}^{3} /$ ha. In general, the lowest total water applied and the lowest estimated ET $_{\mathrm{a}}$ occurred in 2011 because it was a dry year! On the average, the TWA values were higher in Tajikistan than in Uzbekistan. This may be partly due to the tighter monitoring that is exercised on following the irrigation norms in Uzbekistan. Based upon the data in Figure 4, a quadratic relationship $\left(\mathrm{R}^{2}=0.70\right)$ was found between TWA and $\mathrm{ET}_{\mathrm{a}}$, with $\mathrm{ET}_{\mathrm{a}}$ values flattening at higher values of TWA (Figure 5). This relationship between TWA and $\mathrm{ET}_{\mathrm{a}}$ is not a new finding but confirms the existing knowledge [10]. The $\mathrm{ET}_{\mathrm{a}}$ value reaches an upper limit under a given set of climatic conditions; hence, at higher values of TWA, a large decrease in TWA results in a small decrease in $\mathrm{ET}_{\mathrm{a}}$, and thus a small decrease in crop yields. This probably explains why there was no significant difference in the

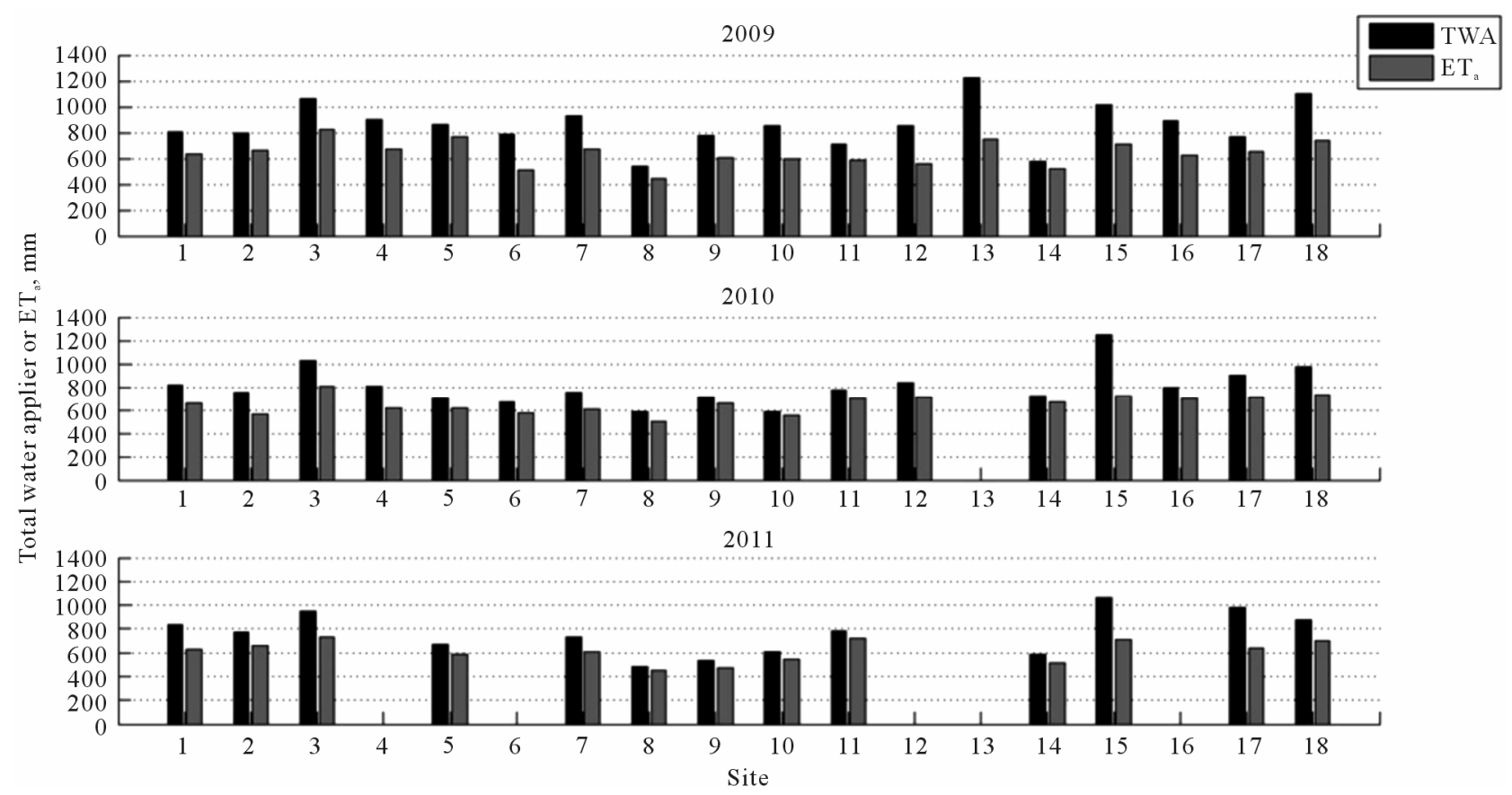

Figure 4. Total water applied and simulated $\mathrm{ET}_{\mathrm{a}}$ values for the demonstration sites. 


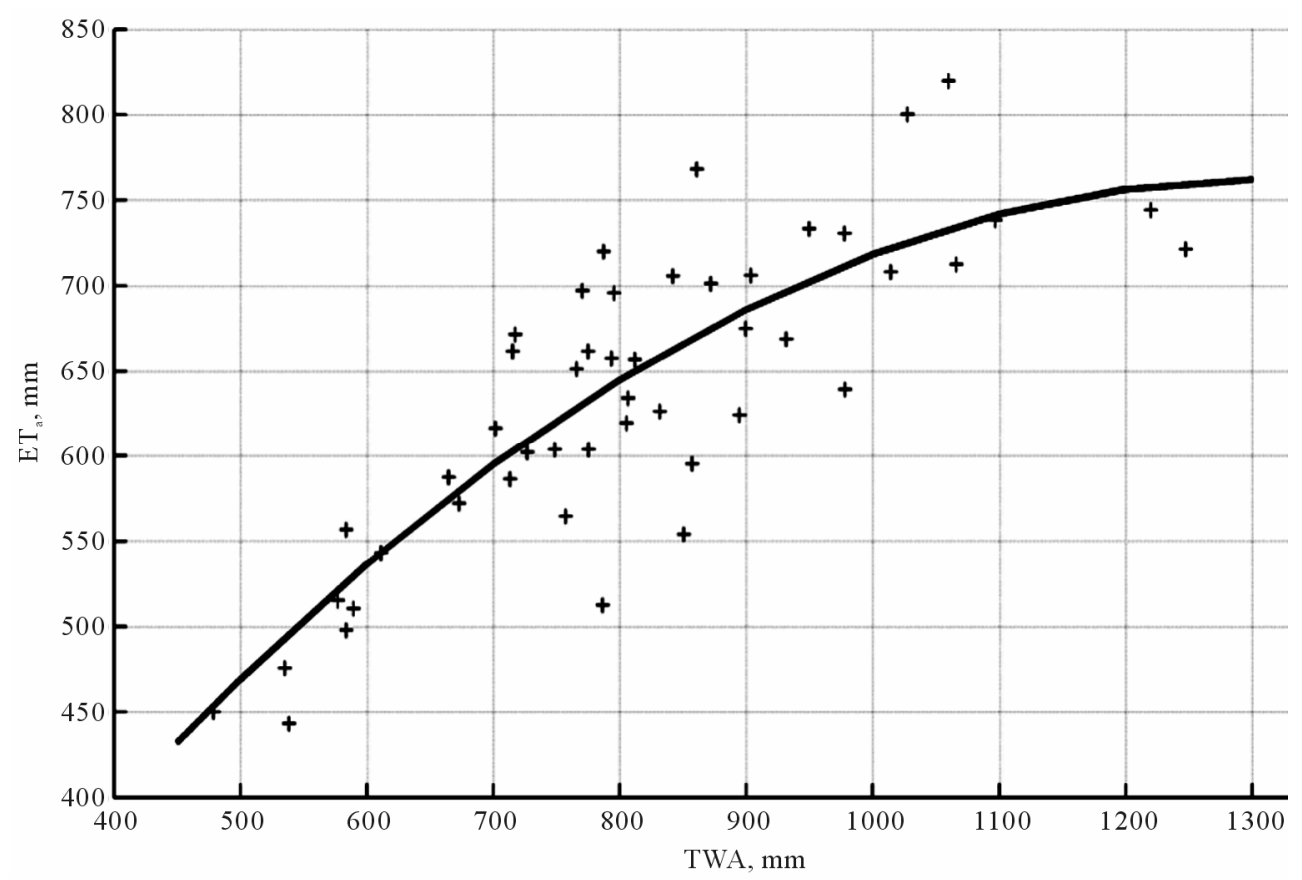

Figure 5. Relationship between total water applied and simulated $\mathrm{ET}_{\mathrm{a}}$ values for the demonstration sites.

average yield of cotton (Figure 3) between 2011 (a dry year) and 2009 and 2010 (wet years).

A regression analysis was also performed between crop yield data (Figure 3) and the simulated $\mathrm{ET}_{\mathrm{a}}$ data (Figure 4) from the demonstration fields. No definite correlation was found between the two variables. This is no surprise because, though water is the most important input for crop production, crop yields at any given location also depend upon a variety of other factors such as crop variety, seed quality and seeding rate per hectare, soil fertility and fertilizer management, plant protection measures used, climatic conditions and degree of unevenness of land surface, etc. The collected data was not sufficient to do a multiple regression analysis between the input variables and crop yields in order to identify the most important input variables for increasing crop yields. Some or all of these inputs, in addition to water, contributed to achieve higher crop yields.

Water productivity (WP) values (Figure 6) were calculated based upon crop yield (Figure 3 ) and $\mathrm{ET}_{\mathrm{a}}$ values (Figure 4). The WP values ranged from $0.35 \mathrm{~kg} / \mathrm{m}^{3}$ to $0.89 \mathrm{~kg} / \mathrm{m}^{3}$, with an average value of $0.58 \mathrm{~kg} / \mathrm{m}^{3}$. The average TWA value was $28 \%$ higher than the $\mathrm{ET}_{\mathrm{a}}$ value, indicating that, on the average, the field irrigation systems were operating at $78 \%$ application efficiency. The remaining $22 \%$ was lost from the fields. However, from a basin perspective, if all of this $22 \%$ water was used by some other farmers somewhere else in the project area or returned to the same stream, then this water was not really lost, implying that no real water savings would accrue by improved application efficiency at field level. However, since more than $60 \%$ of the area irrigated in Tajikistan and Uzbekistan receives pumped water, there would be considerable savings in energy used for pumping irrigation water if the application efficiency is further improved. In addition, there would be a proportionate decrease in the amount of salts returning to the stream. Improved application efficiency is achieved by decreasing surface runoff and/or deep percolation water (from fields) through improved layout of irrigation systems and proper irrigation scheduling [11]. However, improved application efficiency comes at a cost! Therefore, one has to weigh the costs and benefits (reduced energy costs, reduction in salinity of downstream areas and the resulting increases in crop yields, improved reliability of water supply to downstream areas) of improving application efficiency at field level. In this research no $\mathrm{WP}_{\mathrm{I}}$ values were calculated because no information was available on $Y_{D}$ values for the demonstration sites.

Sometimes the average values do not tell the whole story. Therefore, we need to look at the range of values for these variables. For example, the WP values ranged from $0.35 \mathrm{~kg} / \mathrm{m}^{3}$ to $0.89 \mathrm{~kg} / \mathrm{m}^{3}$ which suggest that there is a significant potential for the farmers that are at the lower-end to improve their water productivity through improved water management and/or agronomic practices, depending upon their situation. Similarly, the range of values for $\mathrm{ET}_{\mathrm{a}}\left(4500 \mathrm{~m}^{3} /\right.$ ha to $\left.8000 \mathrm{~m}^{3} / \mathrm{ha}\right)$ suggest that some fields are under-irrigated. Yet, the decrease in yield from the under-irrigated, i.e. deficit irrigated, fields was 

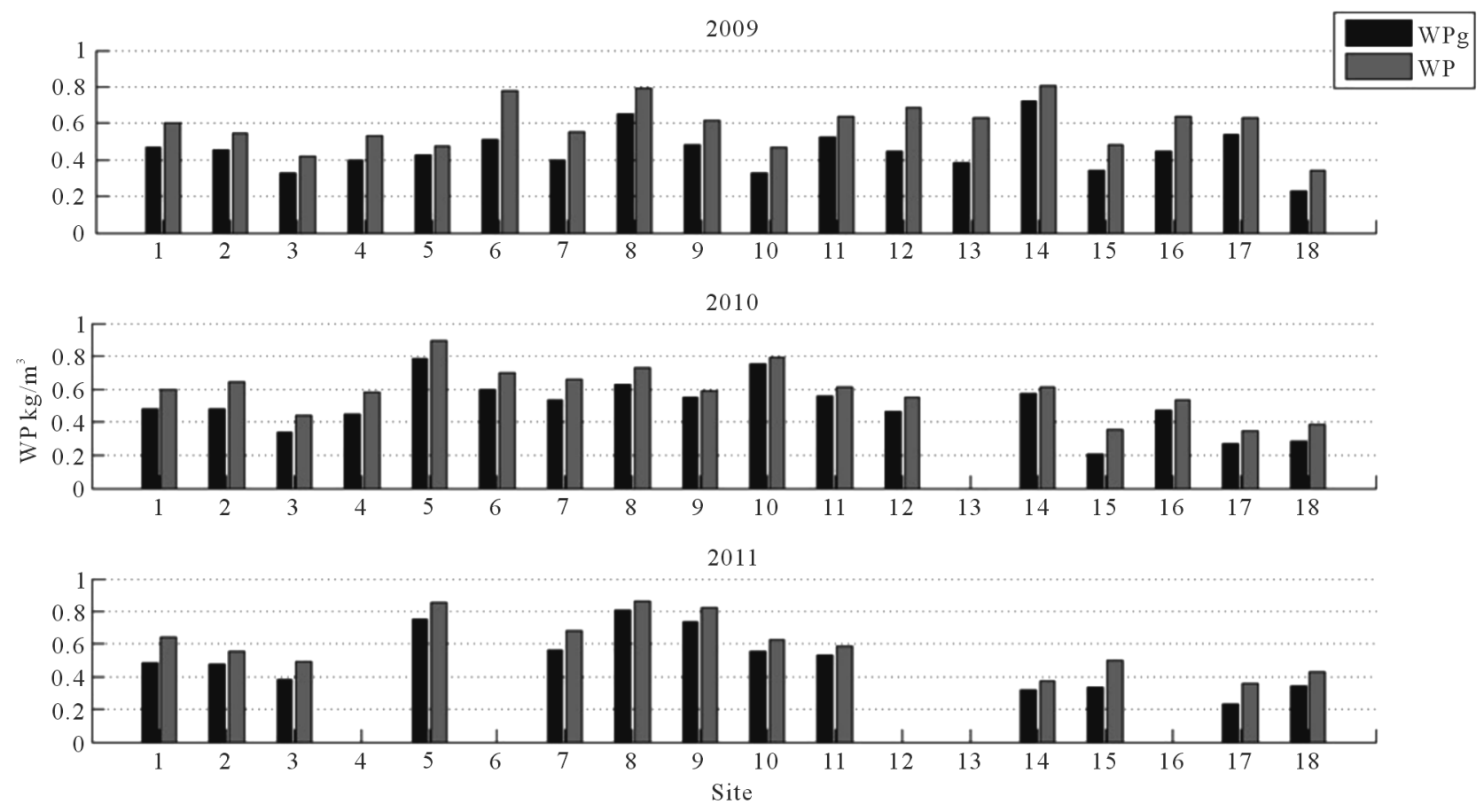

Figure 6. Water productivity and gross water productivity of cotton.

not significantly different from the fields that did not experience water stress, resulting in higher WP. Considering the range of values for TWA and $\mathrm{ET}_{\mathrm{a}}$ indicates that the application efficiency can be significantly lower and higher than the average application efficiency of $78 \%$ in this case. Significantly higher than $78 \%$ application efficiency cannot be achieved without some level of underirrigation, and consequently some reduction in crop yields. Conversely, significantly lower than $78 \%$ application efficiency would result in waterlogging (though it is equally likely that the inefficiency is due to high runoff than deep percolation) and reduced crop yields. This shows the potential for increasing WP by addressing the issue of inequity in water distribution which is a major problem in irrigation projects [12]. Thus there are two avenues for improving water productivity in irrigation projects-through improved technical and agronomic practices at field level, and by improving equity and reliability in water supply to farmers.

Finally, the net profit from crop production was calculated as the difference between gross returns from crop production and the cost of production (Table 3). The net profits ranged from $\$ 173$ to $\$ 1911$, depending upon the quality of cotton lint, irrigation and financial management skills of the farmer, and the market price for cotton. The net profits were higher in years 2010 and 2011 compared to year 2009 because the market price for cotton was higher during 2010 and 2011. The average net profit was higher in Tajikistan compared to Uzbekistan because the farmers in Tajikistan sold their cotton in open market compared to the farmers in Uzbekistan where the cotton was sold to the government at the price fixed by the government. Comparing the data on net profits (Table 3) with the data on WP (Figure 6), it is clear that a high value of WP does not necessarily mean high net profit to the farmer. Because of the earlier mentioned co-benefits of "efficient" irrigation [5], the irrigation system managers would be more interested in improving water productivity through efficient irrigation (deficit or under-irrigation) practices, whereas the farmers are more interested in increasing the net profit per unit area. For farmers, in general, more water means more yields. These objectives are conflicting with each other. From their experience in Tunisia [13], a combination of water pricing and subsidies for improved technologies are required to reconcile this divergence of interests of farmers and irrigation system managers.

\section{SUMMARY AND CONCLUSIONS}

A total of 18 demonstration fields were selected in Fergana Valley (13 in Uzbekistan and 5 in Tajikistan) where the farmers were provided with a set of agronomic and irrigation management interventions to improve yields and water productivity of cotton. The average yields of cotton, for the years 2009, 2010 and 2011, from the demonstration fields and the adjacent fields were, respectively, $28 \%$ and $14 \%$ higher than the average yields for Fergana Valley. The total water applied (TWA) and the $\mathrm{ET}_{\mathrm{a}}$ values were calculated for all the 18 demon- 
Table 3. Cost of production, gross returns, and net returns from the demonstration sites for years 2009-2011.

\begin{tabular}{|c|c|c|c|c|c|c|c|c|c|c|c|c|c|c|c|c|c|}
\hline \multirow{3}{*}{$\begin{array}{l}\stackrel{01}{\check{D}} \\
\stackrel{0}{\circ}\end{array}$} & \multirow{3}{*}{$\begin{array}{l}\text { E } \\
\text { 音 } \\
\text { U }\end{array}$} & \multirow{3}{*}{ Province } & \multicolumn{5}{|c|}{2009} & \multicolumn{5}{|c|}{2010} & \multicolumn{5}{|c|}{2011} \\
\hline & & & \multirow{2}{*}{$\begin{array}{c}\text { Area, } \\
\text { ha }\end{array}$} & $\begin{array}{c}\text { Total } \\
\text { expenses }\end{array}$ & Yield & $\begin{array}{l}\text { Gross } \\
\text { revenue }\end{array}$ & $\begin{array}{l}\text { Net } \\
\text { profit }\end{array}$ & \multirow{2}{*}{$\begin{array}{l}\text { Area, } \\
- \text { ha }\end{array}$} & $\begin{array}{c}\text { Total } \\
\text { expenses }\end{array}$ & Yield & $\begin{array}{c}\text { Gross } \\
\text { revenue }\end{array}$ & $\begin{array}{l}\text { Net } \\
\text { profit }\end{array}$ & \multirow{2}{*}{$\begin{array}{c}\text { Area, } \\
-\quad \text { ha }\end{array}$} & \multirow{2}{*}{$\frac{\begin{array}{c}\text { Total } \\
\text { expenses }\end{array}}{\text { \$/ha }}$} & \multirow{2}{*}{$\begin{array}{l}\text { Yield } \\
\mathrm{kg} / \mathrm{ha}\end{array}$} & \multirow{2}{*}{$\begin{array}{c}\begin{array}{c}\text { Gross } \\
\text { revenue }\end{array} \\
\$ / \text { ha }\end{array}$} & \multirow{2}{*}{$\begin{array}{c}\begin{array}{c}\text { Net } \\
\text { profit }\end{array} \\
\text { \$/ha }\end{array}$} \\
\hline & & & & $\$ /$ ha & $\mathrm{kg} / \mathrm{ha}$ & $\$ /$ ha & $\$ /$ ha & & $\$ /$ ha & $\mathrm{kg} / \mathrm{ha}$ & $\$ /$ ha & $\$ /$ ha & & & & & \\
\hline 1 & $\mathrm{Uz}$ & Andijan & 6 & 834 & 3800 & 1393 & 560 & & & & & & 6 & 1472 & 4000 & 2347 & 875 \\
\hline 2 & $\mathrm{Uz}$ & Andijan & 14 & 821 & 3600 & 1212 & 392 & & & & & & 6 & 1079 & 3600 & 1532 & 453 \\
\hline 3 & $\mathrm{Uz}$ & Andijan & 6.5 & 1096 & 3460 & 1269 & 173 & & & & & & 11.5 & 1178 & 3620 & 1572 & 395 \\
\hline 4 & $\mathrm{Uz}$ & Andijan & 7 & 855 & 3610 & 1221 & 365 & 2 & 948.2 & 3600 & 1310 & 362 & & & & & \\
\hline 5 & $\mathrm{Uz}$ & Andijan & 16.4 & 733 & 3660 & 1637 & 904 & 3 & 1017 & 5500 & 2879 & 1862 & 3 & 1379 & 5000 & 2559 & 1179 \\
\hline 6 & $\mathrm{Uz}$ & Fergana & 4.8 & 857 & 4000 & 1360 & 503 & 4.5 & 577.1 & 4000 & 1593 & 1015 & & & & & \\
\hline 7 & $\mathrm{Uz}$ & Fergana & 2 & 1288 & 3700 & 1607 & 320 & 2 & 731.7 & 4000 & 1246 & 514 & 1 & 1415 & 4100 & 1768 & 353 \\
\hline 8 & $\mathrm{Uz}$ & Fergana & 4 & 648 & 3520 & 1412 & 763 & 4 & 982.9 & 3650 & 1934 & 951 & 0.15 & 1050 & 3887 & 1623 & 573 \\
\hline 9 & $\mathrm{Uz}$ & Fergana & 2.5 & 838 & 3720 & 1116 & 278 & 4 & 622.8 & 3925 & 1557 & 934 & 3 & 756 & 3930 & 1631 & 876 \\
\hline 10 & $\mathrm{Uz}$ & Fergana & 2.2 & 830 & 2800 & 1020 & 190 & 4.2 & 573 & 4420 & 1691 & 1118 & 2.5 & 1122 & 3380 & 1458 & 336 \\
\hline 11 & $\mathrm{Uz}$ & Namangan & 10 & 684 & 3750 & 1294 & 610 & 6 & 1026.4 & 4280 & 1315 & 288 & 10 & 834 & 4210 & 2689 & 1855 \\
\hline 12 & $\mathrm{Uz}$ & Namangan & 2 & 735 & 3800 & 1405 & 670 & 2 & 506.6 & 3900 & 1545 & 1038 & & & & & \\
\hline 13 & $\mathrm{Uz}$ & Namangan & 2 & 857 & 4700 & 1589 & 732 & & & & & & & & & & \\
\hline 14 & Taj & Soght & 2.4 & 873 & 4160 & 1725 & 852 & 2.4 & 1004.4 & 4100 & 2596 & 1592 & 2.4 & 560 & 1900 & 1120 & 560 \\
\hline 15 & Taj & Soght & 4.2 & 763 & 3440 & 3422 & 2659 & 4.2 & 884.1 & 2580 & 1976 & 1092 & 4.2 & 877 & 3548 & 2765 & 1888 \\
\hline 16 & Taj & Soght & 1 & 1067 & 3970 & 1824 & 757 & 1 & 912 & 4150 & 2623 & 1711 & & & & & \\
\hline 17 & Taj & Soght & 1.6 & 944 & 4100 & 1699 & 755 & 1.3 & 749.2 & 3200 & 2023 & 1273 & 1.3 & 651 & 2308 & 1360 & 710 \\
\hline 18 & Taj & Soght & 2 & 966 & 2500 & 2877 & 1911 & 2 & 1112.9 & 2800 & 1949 & 836 & 2 & 1115 & 3020 & 2955 & 1839 \\
\hline
\end{tabular}

stration sites for the irrigation seasons of 2009, 2010 and 2011, and these values for TWA and $\mathrm{ET}_{\mathrm{a}}$ ranged, respectively, from $5000 \mathrm{~m}^{3} /$ ha to $12,000 \mathrm{~m}^{3} /$ ha and $4500 \mathrm{~m}^{3} /$ ha to $8000 \mathrm{~m}^{3} /$ ha, suggesting a quadratic relationship between TWA and $\mathrm{ET}_{\mathrm{a}}$, with $\mathrm{ET}_{\mathrm{a}}$ values flattening off at higher values of TWA. During the three irrigation seasons, the calculated WP values ranged from $0.38 \mathrm{~kg} / \mathrm{m}^{3}$ to $0.89 \mathrm{~kg} / \mathrm{m}^{3}$, indicating that the farmers with a WP value less than the average WP of $0.58 \mathrm{~kg} / \mathrm{m}^{3}$ have a high potential to increase crop yields (and thus WP) through improved irrigation and agronomic practices (including selection of appropriate crop variety). Cotton yields in year 2011 (dry year) were not significantly different from the yields achieved during 2009 and 2010 (wet years), which is basically explained by the quadratic relationship between TWA and $\mathrm{ET}_{\mathrm{a}}$.

On the average, the TWA values were $28 \%$ higher than the $\mathrm{ET}_{\mathrm{a}}$, suggesting an average application efficiency of $78 \%$. The remaining $22 \%$ of the water is lost from individual fields, but may or may not be lost from the basin. This needs to be carefully evaluated for each project. Considering the fact that more than $60 \%$ of the water used for irrigation in Tajikistan and Uzbekistan is pumped from rivers and collector drains, even if all this $22 \%$ of the water returns to the stream without any degradation in water quality, considerable energy savings would accrue from improved water management at field level. Since salinity of return flows is also a major issue in Central Asia, improved efficiency at field level would alleviate the problems of salinity in lower reaches of the river basins. An average application efficiency of 78\% suggests that there were some fields that were underirrigated (yield losses due to water stress), and some fields that were over-irrigated (yield losses due to leaching of fertilizers and temporary waterlogging conditions). Addressing the issue of inequity and reliability in water supply, through improved water management, would also increase crop yields and water productivity from project areas. In general, there is significant potential for increasing water productivity in Central Asia through a combination of improved agronomic and irrigation practices at field level, and improved equity and reliability in 
water delivery to fields.

\section{ACKNOWLEDGEMENTS}

The funding for this research was provided by the Swiss Agency for Development and Cooperation (SDC)-Tashkent office, Uzbekistan, as part of the Water Productivity Improvement at Plot Level (WPI-PL) project. Their financial support is highly appreciated.

\section{REFERENCES}

[1] Abdullaev, I. and Molden, D. (2004) Spatial and temporal variability of water productivity in the Syr Darya basin, Central Asia. Water Resources Research, 40, 1-6. doi:10.1029/2003WR002364

[2] Allen, R., Pereira, L.S., Raes, D. and Smith, M. (2000) Crop Evapotranspiration. FAO Irrigation and Drainage Paper 56, Rome.

[3] Evett, S.R. (2002) Water and energy balances at soilplant-atmosphere interfaces. In: Warrick, A.A., Ed., The Soil Physics Companion, CRC Press LLC, Boca Raton.

[4] Food and Agriculture Organization (1979) Yield Response to Water. FAO Irrigation and Drainage Paper 33, Rome.

[5] Food and Agriculture Organization (1984) Crop water requirements. FAO Irrigation and Drainage Paper 24, Rome.

[6] Gleick, P.H., Christian-Smith, J. and Cooley, H. (2011) Water use efficiency and productivity: Rethinking the basin approach. Water International, 36, 784-798. doi: $10.1080 / 02508060.2011 .631873$
[7] Ibragimov, N., Evett, S.R., Esanbekov, Y., Kamilov, B.S., Mirzaev, L. and Lamers, J.P.A. (2007) Water use efficiency of irrigated cotton in Uzbekistan under drip irrigation and furrow irrigation. Agricultural Water Management, 90, 112-120. doi:10.1016/j.agwat.2007.01.016

[8] Kranz, W., Eisenhauer, D. and Retka, M. (1992) Water and energy conservation using irrigation scheduling with center-pivot irrigation systems. Agricultural Water Management, 22, 325-334. doi:10.1016/0378-3774(92)90040-4

[9] Luquet, D., Vidal, A., Smith, M. and Dauzat, J. (2005) "More crop per drop": How to make it acceptable for farmers? Agricultural Water Management, 76, 108-119. doi:10.1016/j.agwat.2005.01.011

[10] Molden, D.J., Murray-Rust, H., Sakthivadivel, R. and Makin, I. (2003) A water productivity framework for understanding and action. In: Kijne, J.W., Barker, R. and Molden, D.J., Eds., Water Productivity in Agriculture: Limits and Opportunities for Improvement, CABI Publishing, CAB International, Wallingford. doi:10.1079/9780851996691.0001

[11] Murray-Rust, H., Abdullaev, I., Ul-Hassan, M. and Horinkova, V. (2003) Water productivity in the Syr Darya River Basin. Research Report 67, IWMI, Colombo.

[12] Pereira, L.S., Dukhovny, V.A. and Horst, M.G., Eds. (2005) Irrigation management for combating desertification in the Aral Sea Basin: Assessment and tools. Vita Color Press, Tashkent. doi:10.1016/j.agwat.2004.09.041

[13] Reddy, J.M., Matyakubov, B., Jumaboev, K. and Eshmuratov, D. (2012) Analysis of equity and adequacy in water distribution within water users associations of Fergana Valley in Uzbekistan. Irrigation and Drainage Systems, unpublished. 